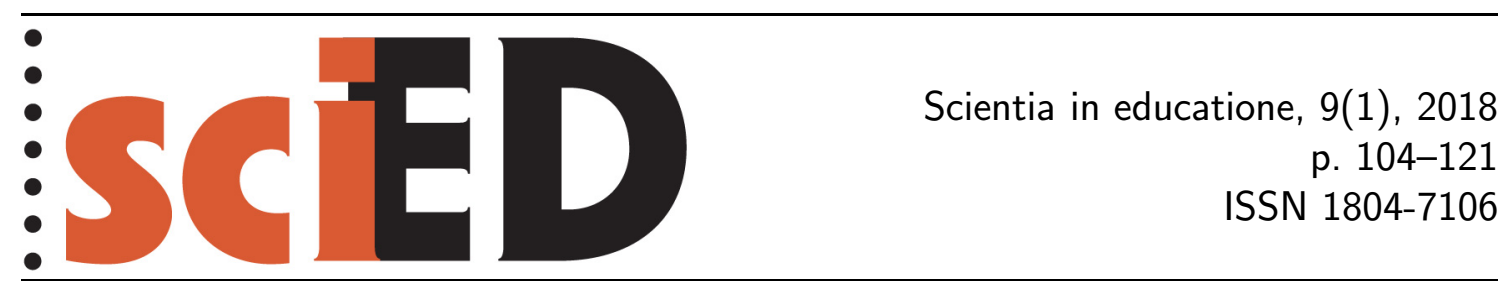

\title{
Využitie pojmového mapovania pri skúmaní predstáv žiakov a študentov o prepojení orgánových sústav \\ Romana Schubertová, Michaela Bednárová
}

\begin{abstract}
Abstrakt
Skúmanie predstáv žiakov a študentov o biologických objektoch a javoch sa v súčasnom didaktickom výskume realizuje pomocou viacerých metód. Podobne ako kresba, aj pojmové mapovanie je jednou z projektívnych metód, vie však poskytnút informácie o kognitívnej štruktúre poznatkov žiaka. V prezentovanom výskume popisujeme predstavy žiakov a študentov o prepojení orgánových sústav človeka a porovnávame ich. Do výskumu sa zapojilo 83 žiakov 7. ročníka na úrovni vzdelávania ISCED 2 a 20 študentov učitelstva biológie v 1. ročníku magisterského štúdia. Z jeho výsledkov okrem iného vyplynulo uprednostňovanie nervovej sústavy vo vztahu k ostatným sústavám, ale aj pevne zakorenená mylná predstava o prepojení vylučovacej sústavy s tráviacou. Naopak, žiaci a študenti vidia malý súvis medzi obehovou a pohybovou sústavou, ktorý je z odborného hladiska zjavný v prenose živín a dýchacích plynov. $\mathrm{V}$ závere poskytujeme návrhy pedagogických implikácií, ktoré môžu ovplyvnit tvorbu a transformáciu identifikovaných mylných predstáv.

Klíčová slova: pojmová mapa, vyučovanie biológie, mylné predstavy, orgánové sústavy človeka, ISCED 2.

\section{Using Concept Mapping to Assess Pupils' and Students' Awareness of the Relationship Between Organ Systems of the Human Body}

Abstract

Recent research in science education has developed several techniques for assessing student awareness and knowledge of biological objects and phenomena. Similar to drawing, concept mapping is one of the projective techniques, yet it can also provide information about the cognitive structure formed by the pupil or student in question. The aim of this research is to describe the prevalent ideas of pupils and students about the interconnection between organ systems of the human body, and to compare these ideas. A total of 83 seventh graders at ISCED 2 level and 20 biology teacher trainees in the 1st year of the Master's study participated in the research. The research established that pupils and students tended to emphasize nervous system in relation to the other systems, but also had a firmly rooted misconception about linking the urinary system to the digestive system. On the other hand, pupils and students proved largely unaware of the relationship between circulatory and muscular systems, even though this relationship is obvious to an expert who considers the transmission of nutrients and breathing gases. As a conclusion we provide some suggestions towards pedagogical implications that can influence the creation and transformation of the misconceptions identified throughout this project.

Key words: concept map, teaching of biology, misconception, organ systems of the human body, ISCED 2. 


\section{1 ÚVOD}

Štúdium mylných predstáv žiakov a študentov v oblasti biologických javov a pojmov je v súčasnom didaktickom výskume realizované rôznymi spôsobmi. Tradičné testovanie, ktoré často poskytuje informácie skôr o schopnosti žiakov reprodukovat naučené, je tak doplňané využitím kresby (Reiss \& Tunnicliffe, 2001), dvojúrovňovými testami (Haslam \& Treagust, 1987), interview (Abdullah \& Scaife, 1997), ale aj pojmovými mapami (Novak \& Gowin, 1984). Aj ked’ je množstvo realizovaných štúdií zamerané na predstavy žiakov o jednotlivých sústavách ludského tela (prípadne živočíchov), tieto predstavy sú skúmané najmä z pohladu stavby a funkcií ich častí, prípadne prepojenia orgánov v rámci jednej sústavy (Teixera, 2002; Garcia-Barros et al., 2011; Stears \& Dempster, 2017; Kubiatko, 2017). Závery výskumov často informujú o nedostatočných predstavách o prepojení orgánov ako zo strany žiakov, tak aj zo strany študentov učitel'stva (Cardac, 2015). Vnímanie vzájomného prepojenia všetkých orgánových sústav, ktoré zdôrazňuje komplexnost’ systému, je však v jednotlivých štúdiách spomínané len okrajovo, ako je to napríklad vo výskume Gungora a Ozgura (2009, podla Cardac, 2015). Tí pomocou kresby žiakov odhalili, že žiaci nevidia prepojenie vylučovacej a močovej sústavy cez obehovú, ale prepojenie prezentujú priamo spájaním jednotlivých orgánov tráviacej a vylučovacej sústavy - táto mylná predstava sa prejavila aj vo výskume Prokopa a Fančovičovej (2006), v ktorom prostredníctvom testu študentka prezentovala, že močový mechúr je priamo spojený s hrubým črevom. Niektoré prepojenia naopak v kresbách žiakov chýbajú, ako to napríklad prezentuje výskum (Stears \& Dempster, 2017). V priebehu interpretácie kresieb si všimli nedostatočné prepájanie pečene s tráviacou sústavou. V oblasti tráviacej, dýchacej a opornej a pohybovej sústavy pritom žiaci v prípade využitia kresby prezentujú najširšie vedomosti (Stears \& Dempster, 2017; Reiss et al., 2002). Kombináciou metód kresba - test s otvorenými otázkami - rozhovor, boli skúmané predstavy žiakov 9. ročníka o ludskom tele vo výskume Enochson et al. (2015). Rozborom troch scenárov s každým respondentom zistili, že integrácia tráviacej, obehovej a vylučovacej sústavy je pre žiakov náročnejšia, ak majú opísat vypitie vody, ako ked’ majú popísat zjedenie sendviča.

Motiváciou ku štúdiu predstáv o prepojení orgánových sústav človeka sú z jednej strany problémy študentov s touto tematikou, ktoré sú badatelné pri vzdelávaní budúcich učitelov biológie, z druhej strany aktuálne preferovanie cielov biologického vzdelávania na vyššej kognitívnej úrovni, ktoré vnímanie tohto prepojenia vyžaduje aj od žiakov na úrovni vzdelávania ISCED 2. Posun úrovne cielov biologického vzdelávania demonštruje inovácia vzdelávacích štandardov z biológie na úrovni vzdelávania ISCED 2, z ktorej je očividný trend ubúdania nárokov obsahového charakteru a zvyšovanie úrovne cielov podla Bloomovej taxonómie (ŠPÚ, 2008, 2014).

Práve inovácia vzdelávacích štandardov poskytla podnet v súvislosti s využitím výskumnej metódy - pojmového mapovania, kedže sa v nej nachádzajú aj štandardy, vyžadujúce od žiakov tvorbu pojmovej mapy. V prípade prepojenia orgánových sústav znie konkrétny štandard nasledovne: „Žiak vie vytvorit pojmovú mapu vztahov orgánových sústav živočíchov" (ŠPÚ, 2014). Využitie pojmového mapovania pri skúmaní pohladu žiakov na prepojenie orgánových sústav je vhodné. Pri tvorbe pojmovej mapy dochádza sprvu k analýze funkcií a významu jednotlivých sústav a ich následnej syntéze, ktorá odráža poznatkovú štruktúru žiakov (Ausubel, 1968). O vhodnosti formulácie vzdelávacích štandardov prostredníctvom pojmového mapovania sa vyjadrujeme, na základe skúseností s ich vyhodnocovaním v tomto výskume, v závere tohto príspevku. 
S počiatkami využitia pojmového mapovania vo vzdelávaní je spojený jeho propagátor Novak, ktorý vo svojom výskume sledoval a snažil sa porozumiet zmenám vo vedomostiach žiakov v oblasti prírodných vied (Novak \& Cañas, 2006). Význam jeho využitia vidia iní autori napríklad vo vizualizácii procesu učenia sa (Nuutinen \& Sutinen, 2003), v potenciáli rozvíjat kognitívne schopnosti žiakov a učit ich rozmýšlat (Irvine, 1995) či v jeho možnostiach diagnostikovat problémy žiakov s vlastným poňatím vzdelávacieho obsahu (Prokša et al., 2008). Využitím pojmových máp bolo skúmané, ako žiaci strednej školy integrujú informácie o tráviacej a vylučovacej sústave (Henno \& Reiska, 2008). Identifikované boli typické nesprávne prepojenia pojmov. Žiaci si napríklad myslia, že jedlo je priamo absorbované do krvi. Pojmová mapa bola využitá aj pri charakterizovaní systémového myslenia v oblasti ludského tela u študentov 10. ročníka (Ben-Zvi Assaraf, Dodick \& Tripto, 2013) a študentov biológie v 11. ročníku (Tripto, Ben-Zvi Assaraf \& Amit, 2013). Z výsledkov vyplýva, že študenti nadhodnocujú pojmy, týkajúce sa štruktúry tela a menej používajú pojmy, ktoré sú procesuálneho charakteru, aj ked’ sú v biológii človeka javy prepojené na úrovni anatomickej, fyziologickej a biochemickej.

Vo výskumnom prostredí biologického vzdelávania sa pojmové mapovanie na našom území zatial neobjavuje, pravdepodobne kvôli náročnej interpretácii dát, ktoré poskytuje. Jej kvalitatívne vyhodnocovanie však umožňuje skúmat aj javy, ktoré výskumník pri konštrukcii iných výskumných nástrojov nedokáže predpovedat. Zároveň, na rozdiel od najznámejších skórovacích techník, poskytuje kompletnejší obraz o predstavách študenta (Zele, Lenaerts \& Wieme, 2004). Skúsenosti s metodikou existujú v prostredí chemického vzdelávania v oblasti výskumu vplyvov inovatívnych postupov vzdelávania na poznatky žiakov (Schubertová, 2014; Bronerská, 2015) či pedagogiky (Bendl \& Voňková, 2010; Janík, 2005). Nakolko domáce zdroje, ktoré poskytujú súhrnne informácie o pojmovom mapovaní sú dostupné (vid' napr. Vaňková, 2014; Karolčík \& Murtínová, 2013), prezentujeme v nasledujúcej časti príspevku len teoretické základy, ktoré ústia do cielov výskumu.

\section{TEORETICKÉ ZÁKLADY POJMOVÉHO MAPOVANIA}

\subsection{TERMINOLÓGIA A TYPOLÓGIA POJMOVÝCH MÁP}

Pojmovú mapu uvádza Davies (2011) ako jednu z možností využitia nástrojov na mapovanie. Ako iné spomína myšlienkové mapy a argumentačné mapy. Myšlienkové mapy, ktoré sú často považované za synonymum pojmových (napr. Karolčík \& Murtínová, 2013), od tohto termínu vymedzuje, k čomu sa v tejto štúdii prikláňame. Sú to skôr asociačné mapy, v ktorých autor hladá kreatívne spojenia medzi svojimi myšlienkami. Využívajú často piktogramy, rôznofarebné zvýraznenia apod., a ich druhou významnou funkciou je uchovanie spojení v pamäti (Buzan \& Buzan, 2012). Naproti tomu sú pojmové mapy viac štrukturované, ich primárnym cielom nie je vytvárat spontánne asociatívne prvky, ale umožnit pochopenie (alebo v prípade nášho výskumu interpretáciu) vztahov. Rozdiely medzi týmito grafickými štruktúrami ilustruje obr. 1.

Z terminologického pohladu je domáca literatúra pomerne nejednoznačná a pojmové mapovanie považuje niekedy za metódu (Stančíková, 2015), inokedy za prostriedok (Adame \& Kováčiková, 2011), nástroj či stratégiu (Mareš, 2010) podla toho, v akých súvislostiach sa o termíne vyjadruje. Pojmové mapy Kimáková (2008) charakterizuje ako grafický nástroj práce s pojmami a triedi ich podla spôsobu prezentácie vztahov, ked’ vymenúva niektoré typy: cyklus, pavúková pojmová mapa, 

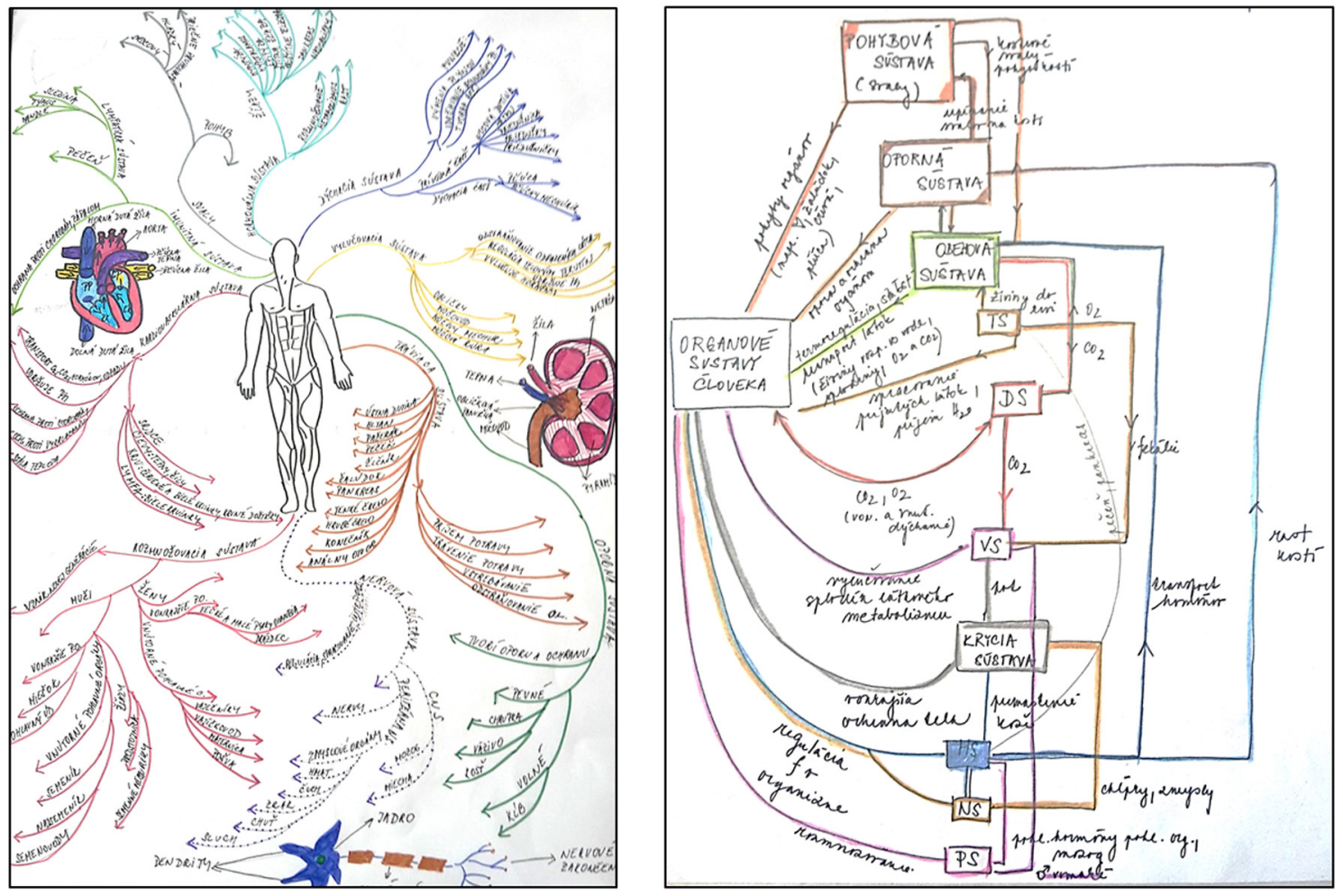

Obr. 1: Rozdiel medzi myšlienkovou a pojmovou mapou na prípade orgánových sústav človeka (Zdroj: anonymná práca študentov)
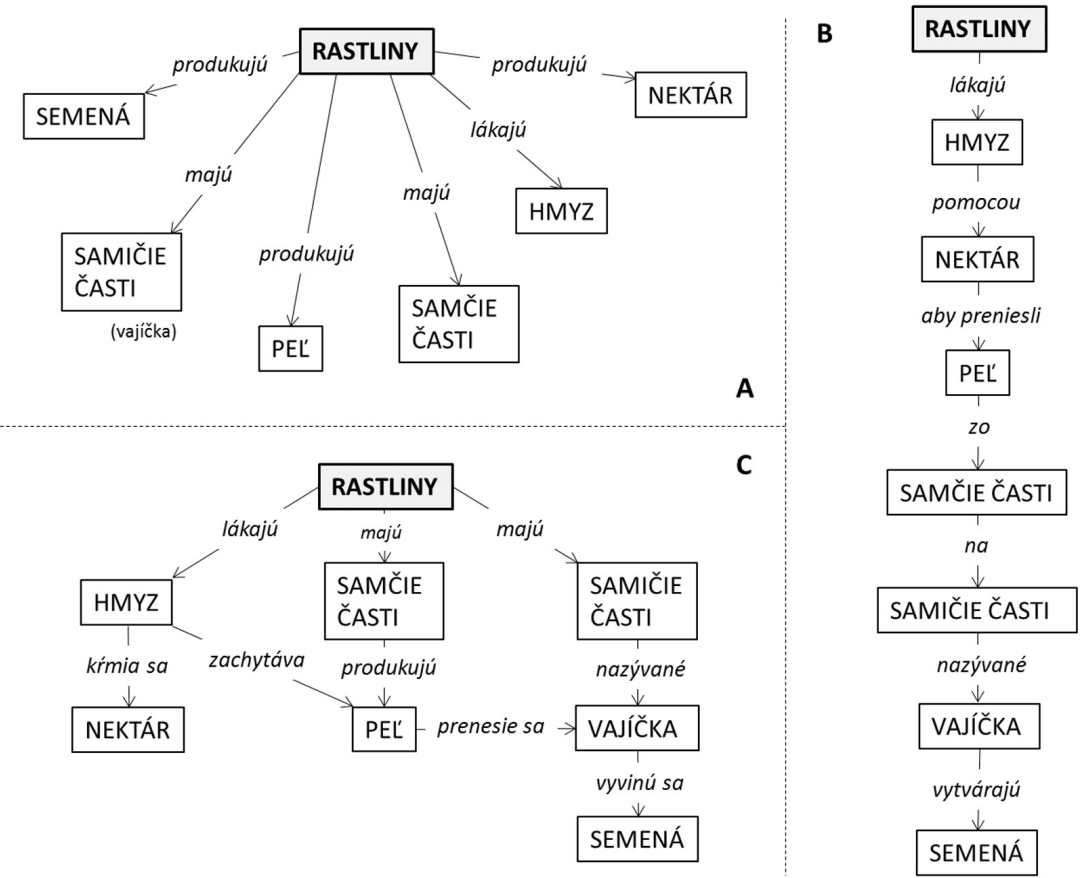

Obr. 2: Tri morfologické typy pojmových máp, ilustrované na jednej téme; A - pavúk, B - retaz, C - siet (Zdroj: upravené podla Kinchin, 2008)

reţaz udalostí, zoskupovanie (zhlukovanie) a iné. Obdobné triedenie využívajú aj iní autori (napr. Prokša et al., 2008), ktorí okrem hierarchickej, pavúkovej, vývojového diagramu a systémovej pojmovej mapy spomínajú aj obrázkový, trojdimenzionálny a mandálový typ. Kinchin (2008) vymenúva tri morfologické typy pojmových máp (reţaz, pavúk a siet - vid’ obr. 2) a pomocou kvalitatívnej analýzy hodnotí ich využitie študentmi vysokých škôl z hladiska prístupu nováčika vs. experta. Expertný 
prístup podla výsledkov jeho výskumu charakterizuje využívanie práve sietového typu pojmovej mapy, preto je možné predpokladat, že frekvencia výskytu takéhoto typu pojmovej mapy bude so skúsenostami (a teda aj s vekom) narastat́.

\subsection{KONŠTRUKTIVISTICKÝ A OBJEKTIVISTICKÝ POHL’AD NA POJMOVÚ MAPU}

Pojmové mapovanie robí v súčasnosti aktuálnym práve kontext rozširovania konštruktivistických teórií do prírodovedného vzdelávania, ktorý aj podla Kinchina (2008) zvýrazňuje epistemologickú trhlinu medzi objektivistickou filozofiou prírodných vied a konštruktivistickou filozofiou pojmového mapovania. Pre biológiu, ale aj iné prírodné vedy, je typický a akceptovaný pohlad na štruktúru poznania hierarchický. V tomto smere sa pojmové mapovanie javí ako vhodný prostriedok, pomocou ktorého vieme formovat žiacke pochopenie smerom $\mathrm{k}$ akceptovatelnému vedeckému pohladu a posúdit aj jednoznačnost’ či správnost takto skonštruovanej pojmovej mapy (vid’ napríklad systém rastlín, či klasifikácia plodov apod.). Konštruktivistický pohlad však nazerá na pojmovú mapu ako na nástroj, dokumentujúci osobnú zmenu žiaka, využíva ju ako „akt skúšky“ - testovania kognitívnej štruktúry. Zviditelnené poznatky dáva priamo do hmatatelnej podoby a dá sa teda s nimi d’alej manipulovat. Práve pojmové mapy, vyžadované prostredníctvom štandardov od žiakov na úrovni ISCED 2 (vid’ ŠPÚ, 2014), majú skôr charakter odhalenia kognitívnej štruktúry, ktoré umožní lepšiu manipuláciu s poznatkami ako charakter pojmovej mapy korešpondujúci s objektivistickou filozofiou prírodných vied. Takéto pojmové mapy sú náročné na objektívnu skórovatelnost’ z hladiska posúdenia jednoznačnosti a správnosti pojmovej mapy, čo už súvisí s ich hodnotením.

\subsection{HodNOTENIE POJMOVÝCH MÁP}

Vaňková (2014) vo svojej publikácii prehladne prezentuje spôsoby hodnotenia pojmových máp a zdôrazňuje, že v súčasnosti využívané dve základné techniky (štrukturálna a vztahová) majú svoje limity.

Strukturálna metóda skúma vlastnú organizáciu pojmovej mapy a sústred’uje sa najmä na meranie počtu pojmov, vztahov, hierarchických úrovní a krížových vztahov. Obdobné hodnotenie je prezentované aj v práci Prokšu a kol. (2008). Výsledkom je celkové bodové hodnotenie pojmovej mapy (najmä hierarchického charakteru), ktoré umožňuje napríklad porovnanie kvality kognitívnej štruktúry u jednotlivých respondentov (vid' Markham, Mintzes \& Jones, 1994). Aj v tomto prípade však závisí od charakteru jej využitia - kým komplexnost́ pojmovej mapy v závislosti od expertného pohladu vo všeobecnosti narastá, pri jej využití k tvorbe výskumného plánu sa naopak so zdokonalovaním znalostí a schopností pojmová mapa zjednodušuje (Dowd, Duncan \& Reynolds, 2015). Zároveň sa charakter mylných predstáv v takto hodnotenej pojmovej mape pri konečnom súčte bodov stráca.

Využitím kategórií, v ktorých môže byt vytvorená pojmová mapa na rozličných úrovniach a slovným opisom týchto úrovní, sa vztahová metóda hodnotenia pojmových máp podobá formatívnemu hodnoteniu. Opis úrovne dáva tvorcovi mapy spätnú väzbu o tom, v čom sú nedostatky alebo silné stránky v danej kategórii. Štandardné kategórie sú napr.: štruktúra, vzţahy, výskumné charakteristiky, informačný charakter a pod. Prístup však môže byt adaptovaný s ohladom na ciel štúdie v prípade hodnotenia systémového myslenia boli napríklad na analýzu použité práve prvky systémového myslenia (Tripto, Ben-Zvi Assaraf \& Amit, 2013). 
Iným spôsobom hodnotenia je porovnanie vytvorenej mapy s kriteriálnou, ktorá predstavuje vzor. V prípade vztahov medzi sústavami by takáto mapa mala obsahovat vzájomné prepojenia všetkých sústav (nakolkko každá s každou súvisí) a opis týchto prepojení.

Na základe uvedeného teoretického rámca a prezentovaných štúdií v oblasti prepojenia orgánových sústav človeka je cielom tohto príspevku charakterizovat prostredníctvom pojmového mapovania mylné predstavy žiakov základných škôl vo vnímaní prepojenia orgánových sústav človeka a identifikovat tie mylné predstavy, ktoré sú z hladiska ich vývoja pevne zakorenené v poznatkovej štruktúre. S ohladom na ciel' boli formulované výskumné otázky:

- Ktorými mylnými predstavami o prepojení orgánových sústav disponujú žiaci 7. ročníka základnej školy?

- Disponujú budúci učitelia biológie obdobnými mylnými predstavami o prepojení orgánových sústav ako žiaci 7. ročníka?

Analýzou týchto dvoch skupín (žiaci a študenti učitelstva) je možné postrehnút vývoj predstáv o vzájomnej závislosti jednotlivých orgánových sústav z pohladu ich funkcií a významu.

\section{Metodika}

Do výskumu sa zapojilo 83 žiakov zo štyroch rozličných tried siedmeho ročníka (12-13 rokov) a troch základných škôl (mestské aj vidiecke) a 20 študentov učitelsstva biológie (v kombinácii s d’alším predmetom), ktorí navštevovali prvý ročník magisterského štúdia (22-24 rokov). Výskum prebiehal v mesiacoch december 2016-marec 2017.

S ohladom na špecifiká dvoch vzoriek (žiaci a študenti učitelstva) boli zvolené postupy tvorby pojmových máp mierne odlišné.

V prípade žiakov sa realizoval zber dát s časovým odstupom od vyučovania daných tém (cca 2 mesiace od sprístupňovania poslednej sústavy), kedy predpokladáme začlenenie poznatkov do kognitívnej štruktúry. Pred zadaním tvorby výskumnej pojmovej mapy prebehlo zaškolenie so spoločnou analýzou pojmovej mapy na tému príroda (pozostávala z 15 pojmov), pri ktorej boli žiaci oboznámení s terminológiou. Následne individuálne tvorili kontrolnú pojmovú mapu, z týchto bežne využivaných pojmov: chodba, kuchyňa, písací stôl, hrniec, topánky, detská izba, kuchynská linka, dom, tanier, postel', sporák, zošit, paplón, vankúš. Zaškolenie sleduje obdobný metodický postup, ktorý vo svojom výskume využili aj Prokša a kol. (2008), či Schubertová (2014). V poslednom kroku tvorili žiaci pojmovú mapu, ktorá bola cielom analýzy - s poskytnutím konkrétnych sústav. Tie usporiadali na základe toho, ako sa vzájomne ovplyvňujú a ako spolu súvisia: nervová, obehová, tráviaca, oporná a pohybová, krycia, vylučovacia, dýchacia. Názvy sústav boli vyberané s ohladom na vzdelávacie štandardy, avšak kvôli korešpondencii so základným prostriedkom učebnicou (Uhereková et al., 2011), bola v priebehu práce na úlohe žiakom poskytnutá informácia, že vylučovacia sústava je synonymom močovej. Žiaci mali na zostavenie pojmovej mapy 25 minút, čo postačovalo k spontánnemu ukončeniu ich práce. Pracovali individuálne. Na základe analýzy kontrolných pojmových máp, z ktorých sa usudzovalo o nepochopení podstaty pojmového mapovania, bolo z pôvodného súboru vylúčených 12 pojmových máp. Výskumný súbor na analýzu pojmových máp orgánových sústav živočíchov teda tvoril 71 pojmových máp. 
V zadaní pre študentov učitelstva nie sú určené konkrétne názvy sústav, a to kvôli ich predpokladaným širším poznatkom z oblasti biológie človeka. Kedže sa vo výsledkoch žiackych pojmových máp ukázalo, že žiaci aj napriek širšiemu zadaniu (orgánové sústavy živočíchov) tvorili pojmové mapy, vztiahnuté len na orgánové sústavy človeka (resp. cicavcov), pre študentov sa kvôli možnosti komparácie zadanie upravilo: „Na základe poznatkov o problematike vytvorte pojmovú mapu, ktorá bude prezentovat vzțahy medzi orgánovými sústavami človeka." Studenti tvorili pojmové mapy v domácom prostredí, bez časového obmedzenia. Zaškolovanie $\mathrm{k}$ tvorbe pojmových máp prebiehalo počas viacerých stretnutí v priebehu štúdia, na ktorých študenti preukazovali dostatočné porozumenie tvorbe pojmovej mapy, preto nebola potrebná tvorba kontrolnej pojmovej mapy.

K vyhodnocovaniu pojmových máp bola využitá zmiešaná metodológia, kombinujúca kvalitatívny a kvantitatívny prístup. V tomto prípade bol zvolený postup od kvalitatívnych údajov ku kvantitatívnym, ktorý mal za ciel rozvoj (použitie výsledkov z jednej metódy pre vývoj a poskytnutie informácií pre inú metódu), ale aj iniciáciu výskumu (objavenie rozporov a paradoxov, ktoré vedú k reformulácii výskumnej otázky) (Green, Caracelli \& Graham, 1989). Oblasti záujmu tak boli identifikované samotným štúdiom vytvorených žiackych pojmových máp, a to prostredníctvom prístupu vynárajúcich sa tém v analýze dát (Wong, 2004). Obdobne ako metóda zakotvenej teórie (Glaser \& Strauss, 1967), aj tento prístup umožňuje pracovat’ s neočakávanými konceptami a je vhodný vo výskumoch, kde sú charakteristické aspekty skúmanej oblasti neznáme. Na rozdiel od zakotvenej teórie je však prístup vynárajúcich sa tém prístupom zhora nadol, takže sa vynárajú najskôr témy široké (Sedlár, 2015). V prvej fáze tak vznikla primárna štruktúra analyzovaných dát, ktorú tvoria nasledovné široké témy:

- typ pojmovej mapy

- vymedzenie centrálneho pojmu

- tvorba špecifických dvojíc sústav.

Vo fáze identifikácie špecifických tém boli pojmové mapy opät̉ analyzované s cielom vytvorenia špecifických tém každej širokej témy (Wong, 2006). Uvedené javy boli následne vyhodnocované kvantitatívne a porovnávané v rámci dvoch skupín respondentov:

- využitie pojmovej mapy sietového typu

- zdôraznenie nervovej sústavy ako centrálneho pojmu

- prepojenie vylučovacej sústavy s tráviacou sústavou

- prepojenie obehovej sústavy s vylučovacou

- prepojenie obehovej sústavy s dýchacou

- prepojenie obehovej sústavy s pohybovou.

Pri špecifikácii typov pojmových máp sa opierame o kombináciu triedenia podla Kimákovej (2008), Kinchina (2008) a Prokšu (2008) (kde lineárny typ stotožňujeme s retazovým a za sietový typ považujeme hierarchickú a systémovú pojmovú mapu). Pri posudzovaní tvorby špecifických dvojíc sústav postup zároveň čiastočne korešponduje s využitím kriteriálnej pojmovej mapy (podl'a Vaňkovej, 2014), kedy boli výskumníkom známe najvýraznejšie prepojenia medzi sústavami a tieto sa pokúšali v posudzovanej pojmovej mape identifikovat. V procese posudzovania validity prepojení boli zároveň indikované chýbajúce a mylné prepojenia, ktoré sú vo výsledkoch dokladované vyjadreniami žiakov, ktoré uviedli nad spojnicami pojmov. 
Pre potrebu porovnania predstáv žiakov 7. ročníka a študentov učitel'stva bol využitý $\chi^{2}$ test so zvolenou hladinou významnosti $\alpha=0,05$, pre ktorú je v prípade stupňa volnosti $\mathrm{DF}=1$, kritická hodnota 3,84 . Do kontingenčnej tabulky boli dosadzované absolútne početnosti výskytu alebo absencie daného javu v prípade obidvoch skupín respondentov.

V prípade, že vypočítaná testovacia charakteristika $\chi^{2}$ bola vyššia ako kritická hodnota, zamietli sme nulovú hypotézu (medzi žiakmi a študentmi nie je vo výskyte pozorovaného javu rozdiel) a vyslovujeme záver o štatisticky významnom rozdiele v ich predstavách.

\section{VÝSLEDKY}

Výsledky sledovania výskytu identifikovaných javov uvádza tab. 1 vo forme absolútnych početností výskytu alebo absencie javu v skupinách respondentov. Podrobnejšie sú výsledky, zodpovedajúce širším témam, rozoberané vo vlastných kapitolách.

Tab. 1: Porovnanie absolútneho počtu výskytu alebo absencie skúmaných javov vo vzorke žiakov 7 . ročníka $(N=71)$ a študentov učitel'stva $(N=20)$

\begin{tabular}{lcc}
\hline absolútny výskyt (absencia) javu vo vzorke & 7. ročník ZŠ & budúci učitelia \\
\hline využitie pojmovej mapy sietového typu & $43(28)$ & $19(1)$ \\
\hline zdôraznenie nervovej sústavy ako centrálneho pojmu & $15(56)$ & $8(12)$ \\
\hline prepojenie vylučovacej sústavy s tráviacou sústavou & $59(12)$ & $8(12)$ \\
\hline prepojenie obehovej sústavy s vylučovacou sústavou & $10(61)$ & $6(14)$ \\
\hline prepojenie obehovej sústavy s dýchacou sústavou & $46(25)$ & $13(7)$ \\
\hline prepojenie obehovej sústavy s pohybovou sústavou & $19(52)$ & $11(9)$ \\
\hline
\end{tabular}

\subsection{TYP POJMOVEJ MAPY}

Z hladiska morfologických typov boli vytvorené pojmové mapy žiakov 7 . ročníka velmi rôznorodé (tab. 2).

Tab. 2: Vyjadrenie výskytu jednotlivých typov pojmových máp, tvorených žiakmi na tému prepojenia orgánových sústav

\begin{tabular}{lccccc}
\hline & \multicolumn{5}{c}{ typ pojmovej mapy } \\
\cline { 2 - 6 } & hierarchická & pavúková & lineárna & systémová & nešpecifikovaná \\
\hline relatívna početnost $(\%)$ & 29,58 & 22,53 & 9,86 & 30,99 & 7,04 \\
\hline
\end{tabular}

Menšie množstvo žiakov $(9,86 \%)$ vníma vztahy medzi sústavami lineárne, čo je s ohladom na charakter reálnych vzţahov medzi nimi vel'mi žiaduce a takéto zobrazenie teda nie je želatel’né. Pomerne častý (30,99 \%) je výskyt pojmových máp systémového charakteru, ktoré naznačujú, že niektoré sústavy vnímajú žiaci ako počiatočné (umožňujú „vstupy“ - napríklad dýchacia alebo tráviaca) a niektoré ako „koncové“ (najčastejšie vylučovacia). Príklady takýchto pojmových máp sú uvedené na obr. 3. 


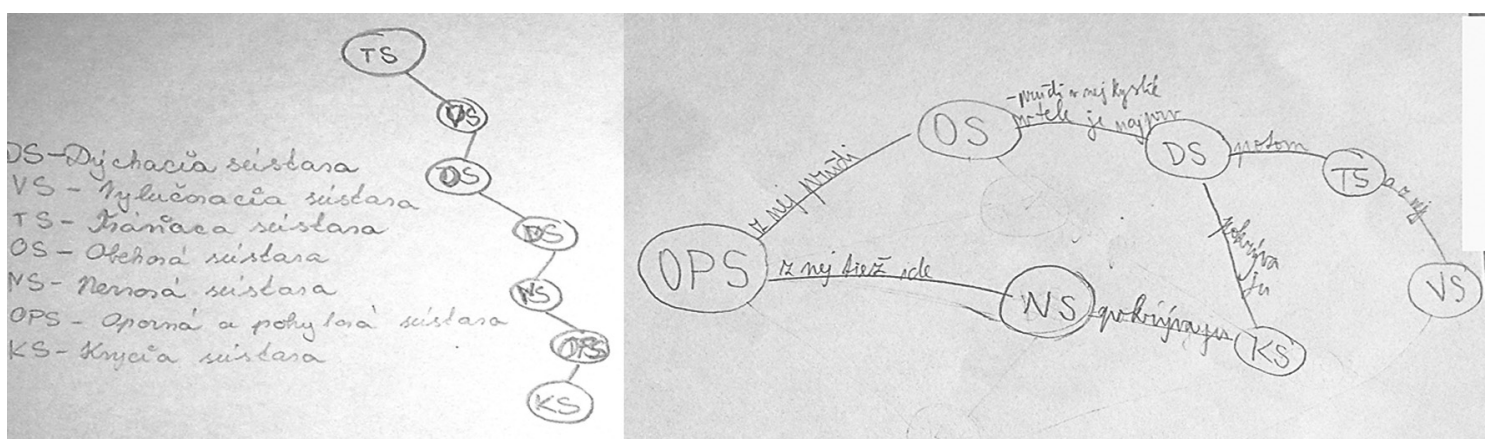

Obr. 3: Typické vyjadrenie lineárnej (nalavo) a systémovej (napravo) pojmovej mapy na tému vztahov medzi orgánovými sústavami (Zdroj: anonymné práce žiakov)

Za vhodné a akceptovatelné zobrazenia (z odborného hladiska reálnych vztahov, pretože zo psychologického hladiska nie je možné hodnotit’ „správnost“" pojmovej mapy) je možné považovat pavúkový a hierarchický typ. Žiaci, ktorí si zvolili pavúkový typ, však mali menej možností na zdôraznenie viacerých vztahov jednej sústavy, často sa z nich dal identifikovat len prístup „rovnocenného vnímania všetkých sústav“ (vid’ obr. 4). Naproti tomu, hierarchická pojmová mapa naznačovala, že niektoré zo sústav majú nadradenú pozíciu, sú dôležitejšie ako ostatné (vid’ tamže).

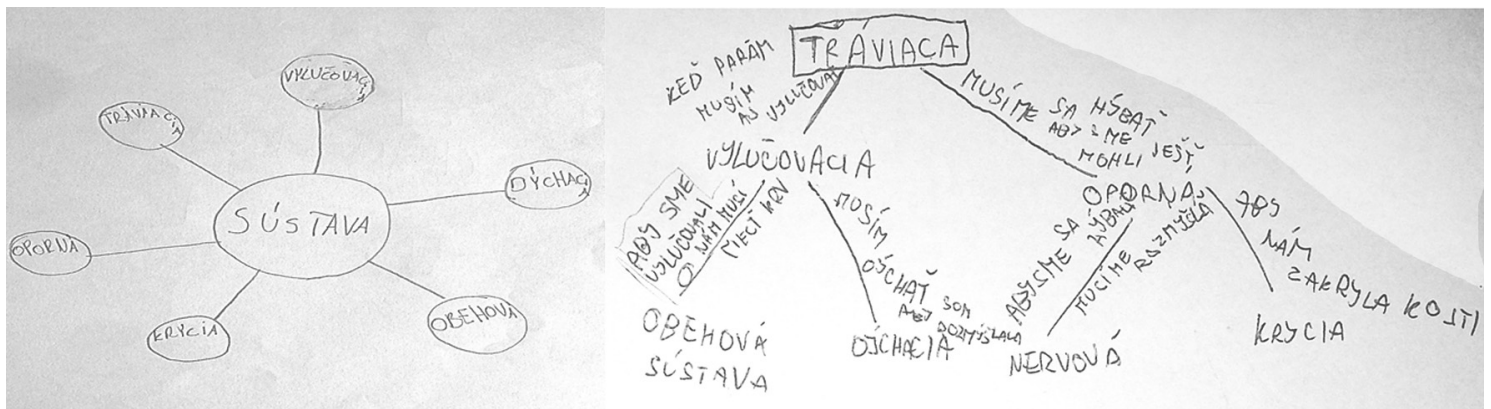

Obr. 4: Vnímanie rovnocennosti jednotlivých sústav, znázornené rovnakou dížkou spojnice od neutrálneho centrálneho pojmu (nalavo) a typická hierarchická reprezentácia s nadradenou pozíciou tráviacej sústavy (napravo) (Zdroj: anonymné práce žiakov)

Ako sme už naznačili, v pavúkovom type bolo čitatelné vnímanie rovnocennosti jednotlivých sústav. Takýto pohlad bol prezentovaný niekedy aj spletou spojení, prípadne vyjadrením pri pojmovej mape, že: „Každá sústava potrebuje každú.“ Z odborného hladiska je predstava správna, previazanost’ funkcií však žiaci nevedia ilustrovat na konkrétnych príkladoch vzţahov, ktoré mali napísat nad spojnicu medzi sústavami.

V prípade pojmových máp, vytvorených študentmi, sa lineárny typ pojmovej mapy nevyskytoval. Velmi sporadický bol cyklický typ, ktorý je typologicky lineárnemu podobný, nakolko z jednej sústavy vychádzajú maximálne dve prezentované prepojenia (obr. 5). Prevažnú väčšinu pojmových máp tvorili hierarchické (podla typológie Kinchina sietový typ), v ktorých bol viac alebo menej identifikovatelný významnejší pojem a množstvo previazaní a vzţahov, reprezentovaných spletou spojníc. Študenti na základe bohatších skúseností s týmto nástrojom častejšie opisovali aj charakter vztahov, z čoho vyplýva jednoduchšia interpretácia a možnost' posudzovat logickú odôvodnenost' vztahov objektívnejšie.

Pri porovnaní vzorky budúcich učitelov a žiakov 7. ročníka existuje štatisticky významný rozdiel vo využívaní pojmovej mapy typu siete, nakolko $\chi^{2}=8,51$. 

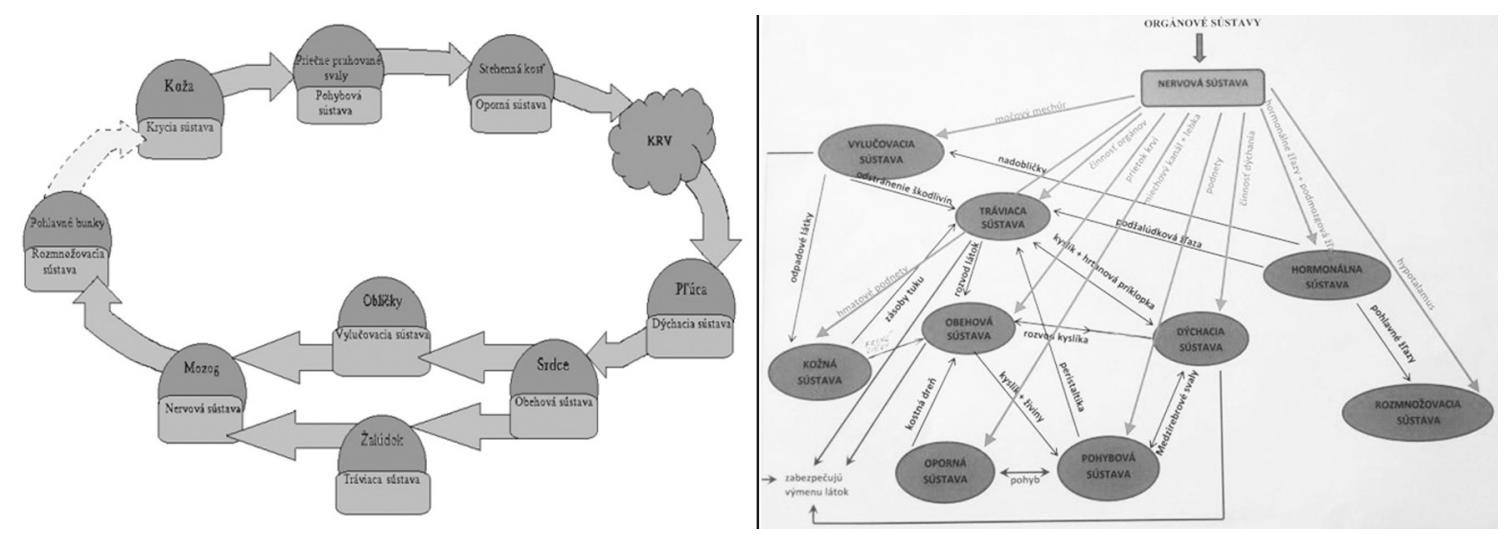

Obr. 5: Preferovaný typ pojmovej mapy na tému prepojenia orgánových sústav človeka je v prípade študentov učitelstva biológie hierarchický (vpravo), ale vyskytuje sa aj cyklický (vlavo), ktorý je podobný lineárnemu typu (Zdroj: anonymné práce študentov)

\subsection{VyMEDZENIE CENTRÁlNEHO POJMU}

Z hladiska centrálneho umiestnenia niektorej zo sústav žiaci 7. ročníka najviac preferovali sústavu nervovú (tab. 3) a je pravdepodobné, že mozog vnímajú ako riadiaci orgán a centrum konania a myslenia.

Tab. 3: Relatívna početnost’ výskytu jednotlivých sústav na najvyššej hierarchickej úrovni u žiakov 7. ročníka

\begin{tabular}{lc}
\hline nadradený pojem & relatívna početnost' (\%) \\
\hline Nervová sústava & 21,13 \\
\hline Oporná a pohybová sústava & 19,72 \\
\hline Dýchacia sústava & 9,86 \\
\hline Obehová sústava & 8,45 \\
\hline Tráviaca sústava & 8,45 \\
\hline Krycia sústava & 5,63 \\
\hline Vylučovacia sústava & 1,41 \\
\hline Potreba nového pojmu & 15,49 \\
\hline Nešpecifikovaný pojem & 9,86 \\
\hline
\end{tabular}

Velmi často sa na hierarchicky najvyššej úrovni vyskytovala aj oporná a pohybová sústava, ktorá je pre žiakov najlahšie pozorovatelná pri bežných činnostiach, ktoré vykonávajú. Umiestnenie tejto sústavy do centra (resp. jej zvýraznenie oproti ostatným, vid’ obr. 6) je z odborného hladiska menej akceptovatelné a je pravdepodobné, že súvisí aj s postupnostou sprístupňovania jednotlivých sústav, kedy sa oporná a pohybová sústava (zároveň) najčastejšie sprístupňuje ako prvá.

V prípade hierarchizácie pojmov sa u študentov učitelstva v centre bud' nevyskytuje žiaden pojem a všetky sústavy sú prezentované ako rovnocenné, alebo je niektorým z rôznych spôsobov zvýraznená nervová (niekedy aj hormonálna) sústava - a to napríklad dvojitým podčiarknutím, zvýraznením inou farbou, umiestnením v najvrchnejšej časti pojmovej mapy. Ak študent nervovú sústavu takýmto spôsobom zvýraznil (40,00 \% pojmových máp), typické bolo, že vnímal jej prepojenie so všetkými ostatnými sústavami (ako ilustruje obr. 5, vpravo). Predstava o výnimočnom 


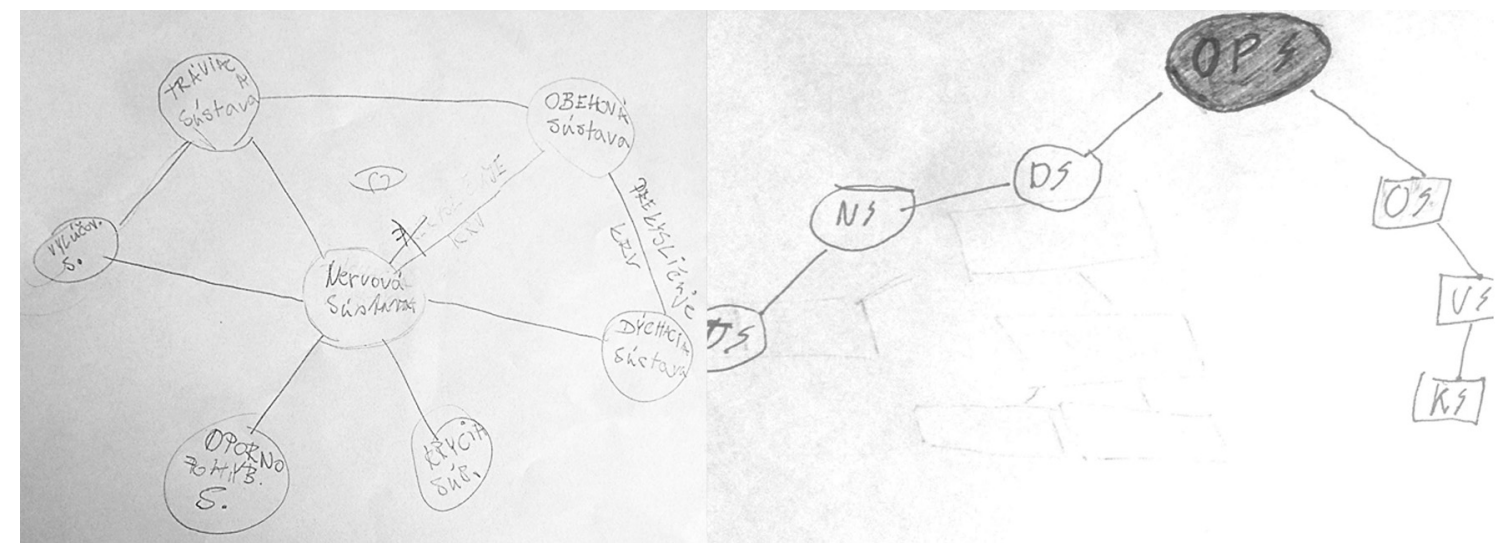

Obr. 6: Rozdielne vnímanie hierarchie jednotlivých sústav u žiakov siedmeho ročníka vlavo v centre nervová sústava, vpravo zvýraznená oporná a pohybová sústava (Zdroj: anonymné práce žiakov)

postavení centrálnej sústavy je pomerne stála, čo potvrdzuje aj testovacia charakteristika $\chi^{2}=0,69$. Medzi žiakmi 7 . ročníka a študentmi učitelstva teda neexistuje štatisticky významný rozdiel v uprednostnení nervovej sústavy ako centrálneho pojmu ich pojmovej mapy.

Ešte komplexnejšie ponímanie vyjadrili študenti, ktorí sa snažili prezentovat to, že každá sústava s každou súvisí, a to aj pomocou charakteristík ich vztahov. Takto vytvorených pojmových máp bolo minimálne množstvo $(10,00 \%)$, pritom práve ich výskyt by bol žiaduci. Z expertného pohladu na význam a jednotlivé funkcie sústav totiž zvýraznenie jednej zo sústav príliš nekorešponduje s reálnou situáciou. Sústavné prezentovanie nervovej sústavy ako „riadiaceho centra“ tak môže v žiakoch a študentoch vyvolávat pocit, že je pre organizmus dôležitejšia ako iné sústavy. Pravdou však je, že jedinou zo sústav, bez ktorých by organizmus dokázal fungovat, je rozmnožovacia. V tomto prípade v 30,00 \% pojmových máp študentov mala rozmnožovacia sústava inú pozíciu ako ostatné (napr. s pojmom ludské telo bola prepojená čiarkovanou čiarou, bola lokalizovaná d’alej od ostatných sústav apod.).

\subsection{TVORBA ŠPECIFICKÝCH DVOJÍC SÚSTAV}

Jedným z najvýraznejších javov, ktorý sa v pojmových mapách žiakov 7. ročníka pravidelne opakoval, bolo spájanie tráviacej sústavy s vylučovacou $(83,10 \%)$, ktoré je často podporené aj zjavnou separáciou týchto dvoch sústav od ostatných (nakreslené d’alej od nich, prípadne úplne oddelené). Žiaci vylučovaciu sústavu (aj napriek tomu, že výskumník na začiatku mapovania vysvetlil, že sa jedná o močovú) následne spájali aj s krycou a dýchacou. Očakávaným by bolo spojenie vylučovacej sústavy s obehovou, práve kvôli filtrácii krvi, čím dochádza k odstraňovaniu škodlivých látok z organizmu. Toto prepojenie sa však vyskytovalo len v 14,08 \% žiackych prác. Na spojnici v tomto prípade uvádzali nasledovné odôvodnenia:

- vylučujem škodlivé látky

- aby sme vylučovali, musí nám tiect́ krv

- lebo v obehovej sústave sa nám čistí organizmus a nevhodné látky vylučujeme

- obehová sústava urýchluje vyprázdňovací proces

- vylučujeme moč

- zlá krv sa vylučuje

- z obehovej sústavy sa krv dostáva do vylučovacej a filtruje sa v obličkách. 
Aj z predložených príkladov žiackych odôvodnení je zrejmé, že ani samotné prepojenie nedemonštruje úplné a správne pochopenie, často je $\mathrm{v}$ ňom prezentovaný nesúlad s vedeckými poznatkami. Akceptovatelné a úplné vysvetlenie prepojenia sa vyskytlo len v jednom prípade (posledná odrážka). Priamo boli mylné predstavy prezentované aj pri spojeniach tráviacej s vylučovacou sústavou, kedy niektorí žiaci tvrdili, že: „Jedlo ide z tráviacej do vylučovacej sústavy.“, alebo že: „Jedlo sa spracuje na živiny a vylučovacou sústavou sa vylúčia škodliviny."

Zaujímavé je sledovat vývoj predstáv o prepojení jednotlivých dvojíc sústav. Prepojenie tráviacej s vylučovacou sústavou sa u budúcich učitelov síce v porovnaní so skupinou žiakov vyskytuje v štatisticky významne menšom počte $\left(\chi^{2}=14,92\right)$, avšak aj tak pomerne často (40,00 \%). Z hladiska spoločného významu týchto sústav by opät ich prepojenie nebolo kategorizované ako mylné, pokial' by sa z opisu charakteru vzţahu nedala táto mylná predstava identifikovat', a to aj ked' nie je charakter vzţahov nad spojnicou popísaný. Napríklad na obrázku 7 je zretel’né, že študent využíva väčšinou ako spojnice obojsmerné šípky, avšak v prípade prepojenia tráviacej s vylučovacou sústavou použil jednosmernú, ktorá pravdepodobne naznačuje, že odpadové látky sa jednosmerne presúvajú z tráviacej do vylučovacej sústavy. Zároveň je síce obehová s vylučovacou sústavou umiestnená pri sebe, čo technicky umožňuje ich jednoduché prepojenie, spojnica sa medzi nimi však nenachádza. Prezentované ponímanie sa nápadne podobá na vnímanie súvislostí žiakov základnej školy, z čoho usudzujeme, že táto mylná predstava dokáže byṫ v kognitívnej štruktúre velmi pevne zakorenená.

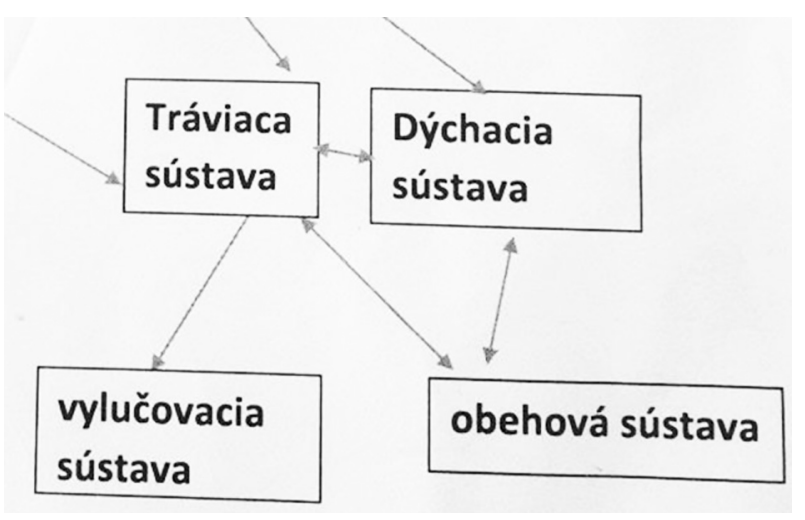

Obr. 7: Príklad neadekvátneho vnímania prepojenia tráviacej a vylučovacej sústavy u študenta učitelstva biológie (Zdroj: anonymná práca študenta)

V porovnaní so žiackymi pojmovými mapami síce narástol počet tých, v ktorých je zvýraznené a správne objasnené prepojenie medzi obehovou a vylučovacou sústavou (30,00 \%), avšak rozdiel vo výskyte tohto spojenia nie je u skupiny žiakov a študentov štatisticky významný $\left(\chi^{2}=2,72\right)$.

Na vytvorených pojmových mapách sa odzrkadlilo, že výrazne zdôrazňovaným je $\mathrm{v}$ školskej praxi vzţah medzi obehovou a dýchacou sústavou. Toto prepojenie vytvorilo až $64,79 \%$ žiakov 7. ročníka, pričom odôvodnenia žiakov sa vo svojej podstate nelíšia a sú jednoznačné, napr.:

- dýchacia sústava okysličuje krv

- dýchaním sa do krvi dostáva kyslík a ten sa potom dostáva do obehovej sústavy. Zaujímavé však je, že tu sa už pomyselná cesta kyslíka pre žiakov končí. Menej často sa totiž objavuje vztah obehovej sústavy s opornou a pohybovou sústavou $(26,76 \%)$. Nakolko sa principiálne jedná o ten istý jav ako v predchádzajúcom 
prípade (spojenie sústav prostredníctvom prenosu kyslíka), predpokladali sme, že výskyt spojení bude rádovo podobný ako u spomínanej dvojice sústav. Uvádzame vybrané doslovné formulácie žiakov, ktorými bol vzţah vyjadrený:

- živiny sa dostanú do kosti a robia ju tvrdšou a pevnejšou

- (obehová sústava) rozváža živiny pre svaly

- krv sa nachádza vo svaloch a tvorí sa aj v kostiach.

V prípade predstáv študentov učitelstva o prepojeniach obehovej sústavy sú výsledky nasledovné:

- s dýchacou ju prepojilo 65,00 \% študentov, čo nepredstavuje štatisticky významný rozdiel oproti výskytu tohto javu u žiakov 7. ročníka $\left(\chi^{2}=0,00031\right)$

- s opornou a pohybovou (alebo jednou z nich) ju prepojilo 55,00 \% študentov, čo je štatisticky významne viac ako v prípade žiakov základnej školy $\left(\chi^{2}=5,63\right)$.

\section{DiskUSiA}

V oblasti typu pojmovej mapy, ktorú si žiaci a študenti volili ako vhodnú reprezentáciu vztahov medzi orgánovými sústavami, prezentované výsledky korešpondujú so závermi Kinchina (2008), že zdokonalovanie predstáv je sprevádzané využívaním prevažne sietovej štruktúry pojmovej mapy.

V prípade vol'by centrálneho pojmu je zretelné preferovanie nervovej sústavy, a to aj u žiakov aj budúcich učitelov. Príčinou tohto fenoménu môže byt', okrem častého zdôrazňovania riadiacej funkcie nervovej sústavy, aj naznačenie usporiadania tela, kedy je mozog uložený v hlave a hlava je oproti ostatným častiam tela postavená najvyššie. Logickým odôvodnením by bolo, ak by bola nervová sústava v centre preto, lebo „inervuje“ ostatné sústavy, a teda má rovnakú úlohu vo vztłahu ku všetkým ostatným sústavám (ako to niekedy bolo zdôraznené v pojmových mapách študentov učitel'stva). Zaujímavé však je, že aj obehová sústava je v takomto vztahu (zabezpečuje výmenu dýchacích plynov pre orgány všetkých ostatných sústav), avšak na najvyššej hierarchickej úrovni sa v prípade žiakov vyskytovala minimálne. Výraznejšie ako obehová bola žiakmi preferovaná oporná a pohybová sústava, čo môže súvisiet so skúsenostami žiaka s touto sústavou. Práve takto vysvetlujú detailnejšie vedomosti prezentované v kresbách aj Stears a Dempster (2017) a Reiss et al. (2002).

U pojmových máp študentov učitel'stva sme pri hladaní centrálneho pojmu identifikovali vyčleňovanie rozmnožovacej sústavy. Situácia naznačuje istú polarizáciu ak má študent vedomost’ o tom, že rozmnožovacia sústava nemá pre existenciu daného organizmu klúčovú pozíciu, snaží sa identifikovat protipól - sústavu, ktorá túto kl'účovú pozíciu má. V uvedenej snahe sa môže vytratit pohlad na komplexnost celého systému.

Výsledky skúmania špecifických dvojíc sústav podporujú závery Gungora a Ozgura (2009, in Cardac, 2015) o mylnom vnímaní vztahov medzi tráviacou a vylučovacou sústavou. Práve v tomto prípade sa ukazuje pojmové mapovanie ako vhodný nástroj na skúmanie tohto fenoménu. Výskyt želatelného prepojenia vylučovacej sústavy s obehovou síce s vekom respondentov narástol, avšak tento rozdiel nie je štatisticky významný a rozvoj správnej predstavy je teda nedostatočný. Z vyjadrení žiakov nad spojnicou pojmov je zrejmé, že v prípade týchto spojení sa prejavila ich osobná skúsenost' z bežného života, $\mathrm{v}$ ktorom si viac uvedomujú význam vylučovania nestrávených zvyškov potravy z tela. Tento príklad vhodne poukazuje na to, ako bráni bežná skúsenost̉ začleneniu „školských poznatkov“ do poznatkovej štruktúry 
žiakov. Na základe častého prepájania vylučovacej sústavy aj s krycou a dýchacou sústavou je možné predpokladat, že žiaci stotožňujú pojmy vylučovanie a vylučovacia sústava a prezentovali tak, že tieto sústavy majú rovnakú funkciu - vylučovanie škodlivých látok.

Okrem identifikovaných mylných predstáv analýza pojmových máp taktiež poukázala na náročnost ich vyhodnocovania, najmä v prípade mladších respondentov s menšou skúsenostou s týmto nástrojom. Aj ked' boli žiaci upozorňovaní na potrebu písania charakteru vztahov nad spojnice pojmov, takéto opisy sa v mapách vyskytovali zriedka. Vhodným riešením by bolo využitie doplnkovej metódy, napríklad rozhovor, využitý ako doplnková metóda ku kresbe v prípade výskumu Enochson et al. (2015), ktorá by pomohla objasnit predstavy žiakov. Obdobné riešenie je navrhované aj v prípade problematického vyhodnocovania kresieb v práci Prokopa a Fančovičovej (2006) a problém nejasnej „čitatelnosti“ sa tak javí u projektívnych metód ako všeobecný. V prípade pojmovej mapy je to zapríčinené aj velkým množstvom dát, ktoré poskytuje, čo sa dá riešit napríklad čiastočnou štrukturáciou riešenia (poskytnutím spojníc a doplňaním pojmov), avšak závery výskumu Ruiz-Primo et al. (2011) konštatujú, že využitie rôznych zadaní ovplyvňuje výsledný obraz o kognitívnej štruktúre respondenta. Obdobná situácia sa však objavuje aj vo využití kresby, kedy zmena inštrukcií vedie k odlišnostiam vo výsledkoch (Prokop \& Fančovičová, 2006). Na rozdiel od kresby, ktorá poskytuje informácie o predstavách žiakov o orgánoch a orgánových sústavách najmä z ich štruktúrneho hladiska (velkost', tvar, umiestnenie), má pojmová mapa potenciál prezentovat́ aj procesuálne hladisko, a teda funkcie jednotlivých orgánov a orgánových sústav a ich vzájomné vztłahy, čo sa potvrdilo v tomto výskume, aj vo výskume (Tripto, Ben-Zvi Assaraf \& Amit, 2013). V spomenutom prípade boli výsledky dokladované konkrétnymi príkladmi dvoch pojmových máp, reprezentujúcich rozličné úrovne systémového myslenia. V prípade tohto výskumu ulahčujú interpretáciu dát komentované ukážky konkrétnych príkladov, ktoré sú v prípade kvalitatívnych výskumov často využívané. Napriek náročnejšej čitatelnosti poskytuje pojmová mapa zaujímavé informácie, ktoré by však pri

jej kvantitatívnom vyhodnocovaní zanikli (napríklad identifikácia separácie pojmov dlhšími spojnicami, alebo spontánne využívanie obojsmerných a jednosmerných šípok, podčiarkovanie pojmov apod.). Tieto momenty, v prípade ak by o nich učitelia vedeli, by mohli byṫ pre nich zaujímavými indikátormi pri využití pojmovej mapy ako diagnostického nástroja v bežnom vyučovaní.

\section{ZÁVER}

Na základe analýzy mylných predstáv o prepojení orgánových sústav človeka je možné vyslovit nasledovné odporúčania pre pedagogickú prax:

- Slabé vnímanie prepojenia obehovej sústavy s opornou a pohybovou - je potrebné klást dôraz na zvýraznenie transportu kyslíka z krvi do svalov, čo sa dá dosiahnut napríklad výskumne ladenou aktivitou, v ktorej bude žiak hladat súvis medzi objemom pretečenej krvi (žiak musí v tomto prípade chápate, že je táto premenná vyjadrená nepriamo, pomocou tepu) a svalovou aktivitou. Bežnejšie sa totiž toto cvičenie vykonáva kvôli lahšej meratel’nosti počítaním nádychov/výdychov, čo zjavne nezabezpečí transfer poznatkov o dýchacej sústave na obehovú sústavu - žiak nevidí priame prepojenie medzi objemom dýchaného vzduchu a pretečenej krvi. 
- Zapájat aktivity na podporu vnímania prepojení - žiaci môžu vytvorit menšie skupiny pričom každá skupina bude reprezentovat jednu sústavu. Problémovou úlohou pre skupinu je nájst' ku každej z ostatných sústav jeden vztah a tieto vztahy si zaznamenat́. Vo vyhodnocovaní vytvoria skupiny, označené názvami svojich sústav, kruh. Prvá skupina povie jeden zo vzţahov a prostredníctvom učitela pošle špagát dotyčnej sústave. Tá si vyberie z ostatných sústav a bude k nej prezentovat vzṫah, ktorého správnost’ ostatní žiaci posudzujú, zas k nej pošle špagát. V konečnom stave bude siet prezentovat spletitost̉ vztahov, ktoré žiaci vyjadrili, čo rieši problém vnímania nadradenosti niektorých sústav.

- Slabé vnímanie prepojenia obehovej sústavy s vylučovacou je pravdepodobne aj terminologickým problémom, v ktorom žiaci vnímajú termíny „vylučovanie“ a „vylučovacia sústava“ synonymne. Klúčové sa javí zdôrazňovanie obličiek ako hlavného orgánu vylučovacej sústavy, pričom žiakom by mohol k vnímaniu prepojenia s obehovou sústavou pomôct vlastný návrh modelu filtrovania krvi, ktorý bude obsahovat aj malý a velký krvný obeh.

Využitie pojmového mapovania ako výskumnej metódy má svoje obmedzenia. Tie sa týkajú najmä náročnej interpretácie, pokial' nie je hodnotená štrukturálnou metódou (ktorá však nie je vhodná v prípade snahy o identifikáciu nových, neznámych mylných predstáv). Kompenzáciu nevýhod by však poskytla kombinácia pojmového mapovania s inou metódou, ktorá by pomohla objasnit charakter prezentovaných vztahov (ako je uvedené v diskusii). Obdobné nevýhody má využitie pojmového mapovania ako diagnostického nástroja vo vyučovaní, preto si myslíme, že formulácia vzdelávacích štandardov prostredníctvom tejto metódy nie je vhodná $\mathrm{v}$ tejto forme nie je stanovený ciel' kontrolovatelný. Využitie pojmovej mapy tohto zadania však môže mat za ciel' zhmotnenie predstáv žiakov, ktoré je následne možné v rámci triedy či seminárov diskutovat̉ a argumentovat', a to najmä v prípade vysokoškolského vzdelávania. V súvislosti s prezentovanými výsledkami výskumu je nutné si uvedomit, že niektoré mylné predstavy sú velmi stále a vyskytujú sa aj u študentov učitel'stva, ktorí sa už v rámci svojho vzdelávania s anatomickými predmetmi stretli. Tieto mylné predstavy o prepojeniach budú pravdepodobne šírit medzi svojich budúcich žiakov a to najmä nedostatočným zdôrazňovaním niektorých vzţahov.

\section{POĎAKOVANIE}

Za cenné pripomienky k textu d’akujeme anonymným recenzentom.

\section{LITERATÚRA}

Abdullah, A. \& Scaife, J. (1997). Using interviews to assess children's understanding of science concepts. School Science Review, 78(285), 79-84.

Adame, R. \& Kováčiková, O. (2011). Prírodoveda 1, metodická príručka pre učitela. Bratislava: Aitec.

Ausubel, D.P. (1968). Educational psychology. A cognitive view. New York: Holt, Rinehart and Winston, Inc.

Bendl, S. \& Voňková, H. (2010) Využití pojmových map ve výuce pedagogiky.

Pedagogická orientace, 20(1), 16-38. 
Ben-Zvi Assaraf, O., Dodick, J. \& Tripto, J. (2013). High school students' understanding of the human body system. Research Science Education, 43, 33-56.

Bronerská, J. (2015). Výskumne ladená koncepcia vzdelávania a periodický zákon [Dizertačná práca]. Trnava: Trnavská Univerzita.

Buzan, T. \& Buzan, B. (2012). Myšlenkové mapy. Bizbooks.

Cardac, O. (2015). Student science teachers' ideas of the digestive system. Journal of Education and Training Studies, 3(5), 127-133.

Davies, M. (2011). Concept mapping, mind mapping and argument mapping: what are the differences and do they mater? The International Journal of Higher Education, $62(3), 279-301$.

Dowd, J. E., Duncan, T. \& Reynolds, J. A. (2015). Concept maps for improved science reasoning and writing: Complexity isn't everything. CBE - Life Sciences Education, 14, $1-6$.

Enochson, P. G. et al. (2015). Ideas about the human body among secondary students in South Africa. African Journal of Research in Mathematics, Science and Technology Education, 19(2), 199-211.

Garcia-Barros, S. et al. (2011). What do children aged four to seven know aboout the digestive system and the respiratory system of the human beeing and of the other animals? International Journal of Science Education, 33(15), 2095-2122.

Glaser, B. G. \& Strauss, A. L. (1967). The discovery of grounded theory. New York: Aldine.

Greene, J. C., Caracelli, V. J., Graham, W.F. (1989). Toward a conceptual framework for mixed.method evaluation design. Educational Evaluation and Policy Analysis, 11(3), $255-274$.

Grubb, R. (2017). Roots of visual mapping. Dostupné z http://www.mindmapping.org/blog/mapping-history/roots-of-visual-mapping/

Haslam, F. \& Treagust, D. F. (1987). Diagnosing secondary students' misconceptions of photosythesis and respiration in plants using a two-tier multiple-choice instrument. Journal of Biological Education, 21(3), 203-211.

Henno, I. \& Reska, P. (2008). Using concept mapping as assessment tool in school biology. Proc. of the third conference on concept mapping, Tallin, Estonia \& Helsinki, Finland.

Irvine, L. (1995). Can concept mapping be used to promote meaningful learning in nursing education? Journal of Advanced Nursing, 21, 1175-1179.

Karolčík, Š. \& Murtínová, L. (2013). Možnosti aplikácie pojmových máp vo výučbe geografie na vyššom stupni sekundárneho vzdelávania. Moderní vyučování.

Dostupné z http://http://www.modernivyucovani.cz/uspenos-zaradeniapojmovych-mapdo-programu-vyuby-geografie-na-niom-stupni-sekundarnehovzdelavania/

Kimáková, K. (2008). Úvod do štúdia didaktiky biológie. Košice: Univerzita Pavla Jozefa Šafárika v Košiciach.

Kinchin, I. M. (2008). The qualitative analysis of concept maps: some unforseen consequences and emerging opportunities. In Proceddings of the third international conference of concept mapping. Tallin, Estonia \& Helsinki, Finlad.

Kubiatko, M. (2017). Predstavy žiakov o vylučovacej a endokrinnej sústave. Scientia in Educatione, 8(2), 70-83. 
Mareš, J. (2010). E-learning využívajíci objektivní a subjektivní mapy pojmů. Dostupné z https://konference.osu.cz/icte/dokumenty/2010/mares.pdf

Markham, K. M., Mintzes, J. J. \& Jones, M. G. (1994). The concept map as a research and evaluation tool - further evidence of validity. Journal of Reasearch in Science Teaching, 31(1), 91-101.

Novak, D. J. \& Cañas, J. A. (2006). The theory underlying concept maps and how to construct and use them. Príspevok prezentovaný na Technical Report IHMC Cmap Tools, Florida. Dostupné z http://cmap.ihmc.us/Publications/ResearchPapers/TheoryUnderlyingConceptMaps.pdf

Novak, D. J. \& Gowin, D. B. (1984). Learning How to Learn. New York: Cambridge University Press.

Nuutinen, J. A. \& Sutinen, E. (2003). Visualisation of the learning process using concept mapping. In Proceedings 3rd IEEE international conference on advanced technologies. Athens, Greece.

Prokop, P. \& Fančovičová, J. (2006). Students' ideas about the human body: Do they really draw what they know? Journal of Baltic Science Education, 2(10), 86-95.

Prokša, M. et al. (2008). Metodológia pedagogického výskumu a jeho aplikácia $v$ didaktikách prírodných vied. Bratislava: Univerzita Komenského.

Reiss, M. J. \& Tunnicliffe, S. D. (2001). Students' understandings of human organs and organ systems. Research in Science Education, 31(3), 383-399.

Reiss, M. J. et al. (2002). An international study of young people's drawings of what is inside themselves. Journal of Biological Education, 36(2), 18-22.

Ruiz-Primo, M. A. et al. (2011). On the validity of cognitive interpretations of scores trom alternative concept-mapping techniques. Educational Assessment, 7(2), 99-141.

Schubertová, R. (2014). Induktívne osvojovanie pojmu látkové množstvo [Dizertačná práca]. Trnava: Trnavská Univerzita.

Sedlár, M. (2015). Systematické prístupy k analýze dát z Metódy kritických rozhodnutí. Psychologie a jeji kontexty, 6(2), 79-93.

Stančíková, D. (2015). Myšlienková mapa ako výsledok činnosti žiakov na hodinách ekonomiky a práva. Bratislava: Metodicko-pedagogické centrum.

Stears, M. \& Dempster, E. R. (2017). Changes in children's knowldge about their internal anatomy between first and ninth grades. In P. Katz (Ed.), Drawing for science education: An international perspective (147-154). Rotterdam: Sense Publishers.

ŠPÚ. (2008). Štátny vzdelávací program pre 2. stupeň základnej školy v Slovenskej republike, ISCED 2 - nižšie sekundárne vzdelávanie.

Dostupné z http://www.statpedu.sk/sites/default/files/dokumenty/statny-vzdelavaciprogram/isced2_spu_uprava.pdf

ŠPÚ. (2014). Inovovaný štátny vzdelávací program. Biológia.

Dostupné z http://www.statpedu.sk/sites/default/files/dokumenty/inovovanystatnyvzdelavaci-program/biologia_nsv_2014.pdf

Teixera, F. M. (1998). What happens to the food we eat? Children's conceptions of the structure and function of the digestive system. In Proceedings of the second conference of European researchers in didactic of Biology. University of Göteborg, Sweden. 
Tript, J., Ben-Zvi Assaraf, O., Amit, M. (2013). Mapping what they know: Concept maps as an effective tool for assessing students' systems thinking. American Journal of Operations Research, 3(1), 245-258.

Uhereková, M. et al. (2011). Biológia pre 7. ročník základnej školy a 2. ročník gymnázia s osemročným štúdiom. Bratislava: EXPOL PEDAGOGIKA.

Vaňková, P. (2014). Pojmové mapy ve vzdělávání. Univerzita Karlova v Praze: Katedra informačních technologií a technické výchovy.

Dostupné z http://vzdelavani-dvpp.eu/download/opory/09vankova.kn.blA4.TISK.pdf

Wong, B. L. W. (2004). Critical decision method data analysis. In D. Diaper \& N. A. Stanton (Eds.), The Handbook of tasks analysis for human computers interaction (327-346). Mahwah, New Jersey: Lawrence Erlbaum Associates.

Wong, B. L. W. (2006). The critical decision method. In W. Karwowski (Eds.), International encyclopedia of ergonomics and human factors: Volume 1 (2nd ed.) (3067-3073). Boca Raton: Taylor \& Francis.

Zele, E. V., Lenaerts, J. \& Wieme, W. (2004). Improving the usefulness of concept maps as a research tool in science education. International Journal of Science Education, 26(9), 1043-1064.

ROMANA SchuberTOVÁ, romana.schubertova@umb.sk

MichaEla BEDNÁRovÁ, bednarova.michaela13@gmail.com

Univerzita Mateja Bela, Fakulta prírodných vied

Katedra biológie a ekológie

Tajovského 40, Banská Bystrica, Slovakia 